\title{
Assessment of Critical Challenges Facing Small Business Enterprises: A Survey of Small Businesses in Woliso Twon, Ethiopia
}

\author{
Solomon Terfasa Dinka \\ Lecturer, Department of Accounting and Finance, Ambo University, Ethiopia
}

\begin{abstract}
Small businesses development has received a great attention as priority area for economic growth and transformation mainly for emerging economies. The study aimed to assess the challenges facing small business enterprises of Woliso town, Ethiopia. The research type used in the study was descriptive research. The study employed the primary data which obtained from small business owners through questionnaires. The total population of the study was 940 small business enterprises and out of which 272 was taken as a sample using probability sampling technique. Data obtained from primary sources were processed through SPSS version- 22 . Finally, to assist the interpretation processes pie charts, frequency tables, and bar graphs were used. The study concluded that, access of finance, informal business sectors, high tax rate, bureaucratic leadership, lack of accounting skills, shortage of finance, were potential challenges of small business enterprises in the study area. The study suggested that, there is a need for short term training, workshops, and seminar in order to fill the skill and knowledge gap of small business owners.
\end{abstract}

Keywords: Critical, Challenges, Small Business Enterprises

DOI: $10.7176 /$ RJFA/10-3-04

\section{Introduction}

The fact that small businesses enterprises play a critical role in economic transformation, they attract the attention of many developing countries. For instance, in present time, countries such as China, Taiwan, South Korea etc. have shown remarkable changes in their economy through the promotion of their small scale enterprises. Likewise, Ethiopia is one of the fastest growing economies in the world. Small business sector supports most part of Ethiopian economy by providing numerous socio-economic benefits to the majority of its citizens. However, in spite of its vast contribution, its success still falls below expectations (Arinaitwe, 2006).

According to Osinowo, (1997) most African countries are basically agrarian societies with the majority of the populace engaging in agro-related activities. It is un questionable that, the process of industrialization should be based on the development of the small businesses sectors to link agricultural production with manufacturing activities. This requires specific incentives to support in the development of the SMEs subsector, which comprise among others easy access of funds, infrastructural facilities, and industrial extension services. In continent of Africa, small business enterprises are faced with several difficult problems. According to Brinders et al, (2003) the main challenges facing African countries small business are absence of global competition resulting from lack of access to finance, business knowledge and skills, poor culture of businesses, and the lack of available working capital premises.

According to Ethiopia National Planning Commission, (2015) although promising progresses have been made in the economy, employment generation, poverty reduction the issues of small business enterprises are still key development agenda. In line with this, Ethiopia is highly committed to sustain inclusive and pro-poor development strategy over the next years to further promote small scale enterprise so as to achieve its bold journey for industrialization. Small business sector has been identified as important tool for economic transition by providing goods and services with a better quality at reasonable price for many people without requiring highlevel training and huge finance (ILO, 2008). Lara and Simeon, (2009) further indicated that, small businesses generate substantial employment and economic output in most countries. Their share overall employment tends to be higher in developing countries, which are typically more focused on small-scale productions.

Small businesses in Ethiopia are nevertheless experienced with numerous challenges that affect their growth potential. For instance, according to Werotew, (2010) these major factors include financial problems, lack of qualified employees, marketing problems and lack of work premises among other. Mbugua, (2014), Babandi, (2017) also added that, lack of proper government policy, access of finance, financial information, educational and professional background of owners and managers were the most important challenges of small businesses.

\section{Research Problem and Objectives}

Know days, rapid industrialization is one of the most pressing need for many emerging economies. The small enterprises occupy a strategic position and play a crucial role in fulfilling the socio-economic objectives of any nation. According to Ethiopian Development Research Institute, (2017) even though, the growth of small 
enterprises has been received a great attention as a means of poverty reduction and employment creation still there is broad gap of knowledge and information about this sub-sector. For instance, limited knowledge concerning the conditions in which small business owners are operating and major challenges facing small business are few among others. Most businesses are intended to remain small and unsuccessful, more suited for dominance in the local market than dominance on a national scale. Similarly, they tend to generate far less profit than large-scale businesses, mainly because they exist in a localized market and don't have access to finance to expand operation and attract a large number of customers (Dekisiso, 2018).

Small business enterprises usually don't have adequate funds in order to meet their working capital and fixed capital needs. In this regard, financial institutions are generally lack confidence to lend money to small business owners mainly because of small business owners are not in position to offer the collateral required by lending institutions and limited capacity to repay the loan (Fetene, 2010). In fact, in adequate finance are the critical problem faced by small business sector. For instance, according to Neale and Wickramage, (2006) another critical problem currently facing small businesses enterprise in many country is the existence of informal sectors activities in the economy. In fact, most people argued that, the existence of informal business sectors create a culture whereby formalized businesses are tempted away from complying with employment rule. On the other hand, Slemrod and Venkatesh, (2002) indicated that, unreasonable taxes of small businesses are another common problems facing small businesses.

In line with the above state of affairs, one can recognizes that, the full potential of small businesses has not yet maintained due to a number of challenges facing small business enterprise. Thus, critical attempts have to be made to enhance the full capacity of this sector so as to bring sustainable social and economic progress in the country in general and in Woliso town in particular. Hence, the study was designed to assess the critical challenges facing small business enterprises of Woliso town.

\section{Literature Review}

\subsection{Overview of Small Businesses}

Development theories have postulated the alternative use of small businesses sectors to accelerate economic growth and transition particularly in emerging economies (Daodu, 1997). The significant social and economic importance of small businesses is unquestionable. The success and failure of transitional economy highly relied on the growth and achievement of small business owners (McMillan and Woodruff, 2002). According to Sievers and Vandenberg, (2007) owners of small businesses are not only engaged in income creation for their households but also, they generate income and employment opportunities for citizens. Moreover, small businesses are considered as important element of a healthy and vibrant economy.

\subsection{Challenges Facing Small Businesses}

In fact, there are a number of challenges facing the development and success potential of small business sectors. These challenges are normally interdependent and very often relate to each other. Some of these challenges emphasized in this study are presented as follows.

\subsubsection{Access to Finance}

In Ethiopia, as it is pointed out by Zeleke, (2009) small business operation is fall below expectations mainly because of in adequate credit and excessive government regulation. He further adds that, very few small scale enterprise obtained loan from formal banks due to the collateral requirement asked by banks. In line with this, at their set up phase most of them were supported by their own savings and loan from friends and micro finance institutions. According to Wakjira, (2015) the main bottleneck for the growth and survival small business firms are insufficient working capital and lack of collateral.

\subsubsection{Managerial Skill}

Hall, (1992) pointed out that, the crucial causes of small business failure appear to be a lack of proper managerial skills. Longenecker et al, (2006) also adds that lack of proper planning, financing, and poor management are the major causes for the failure of small enterprises. Most owners of small business sector have no vocational training and adequate level of education. Although, professional managers are very much important for the sustainable growth of small businesses still lack managerial skill is a key challenge for small businesses growth in developing countries like Ethiopia (Zeleke, 2009).

\subsubsection{Taxing System}

Okoye and Ezejiofor, (2014) suggests that, a tax system of nation is very crucial factors in small business development. Thus, in order to support small business sectors tax system has to be good as possible. In case of Ethiopia, according to Federal income tax Proclamation No. 979/2016, Article 3 the taxing system for the vast majority of small business owners is based on estimation. In line with this, in Ethiopia, evidences shows that the taxing system implementing in small businesses sectors are not good so that, questions have been raised always in small business sector. 


\subsubsection{Informal Business Sectors}

It was in 1970s, that informal sector became a common agenda for the world economy. In present time, this sector has grown around the world and it is the largest economy in many countries. Many people argued that, informal business sectors have negative and positive effects on social and economic activities. In Ethiopia, now days informal business sectors are becoming the most challenges problems. Different advocators suggest that as size of informal sectors becoming wider and wider it adversely affects the economy in general and formal business sector in particular. Moreover, according to Neale and Wickramage, (2006) informal business sectors have created: (1) a culture whereby formalized businesses are tempted away from complying with employment law, (2) informal employment weakens collective bargaining, thereby worsening workers rights, (3) tax avoidance and benefit fraud results in a loss of state revenue, which in turn hinders the ability of government to pursue socially beneficial initiatives, (4) loss of state revenue may cause a rise in taxes which can in turn encourage an expansion of the informal economy.

\subsubsection{Accounting Skills}

Accounting provides necessary information which serves as a business language. Thus, small business owners need to have proper accounting knowledge and skill in order to successful in their operation. For instance, Akande, (2008) suggested, small business owners should posses all necessary accounting skill and ability so as create value for their firms. In fact, most owners of small businesses have no enough accounting skill which helps them to better manage their operation in general. A study by Collis and Jarvis, (2002) indicated that, there is limited usage of financial and management accounting reports by small businesses. The study further revealed that, a kind of accounting reports maintained by small businesses are typically limited to a few types of simple reports such as profit and loss account.

\subsection{Reviews of Empirical Studies}

Over the year, different researches have been made on challenges facing small business development in different Countries. However, research findings that evaluate critical challenges affecting small businesses are very few in number. Moreover, these challenges are varied from country to country. In Ethiopia, there is no prior empirical evidence relates to critical challenges facing small business sectors. Thus, it is very crucial to provide additional empirical evidences so that better insight regarding those critical challenges facing small business enterprises. The following section summarizes some empirical studies related to the topic.

Sanjay, (2005) done an extensive study related to the challenges facing small businesses on global perspective. The study concluded that, the main challenges facing developing countries lack of global competition resulted from lack of human resource, development skills, and access to adequate finance. In addition, the study further indicated that, lack of business knowledge and skills, poor culture of enterprise, and the lack of available working capital are another bottleneck of small businesses. A study done by Wellington and Mpendulo, (2008) on current challenges and problems facing small and medium size contractors in Swaziland revealed the most influencing factors hinder the progress of small business in Swaziland were related to access to capital, shortage of managerial skills and lack adequate support from government bodies. Menna, (2013) done an investigation on factors affecting the performance of small and medium enterprises in the manufacturing sector of Cairo, Egypt. The results indicated lack of finance, lack of financial and marketing management skill were the most pressing problems of small businesses.

Mubugua, (2014) assessed factors affecting the performance of small and micro enterprises in Limuru town of Kenya, his study concluded that access to finance and availability of management experience were the key socio-economic factors affecting the performance of businesses in Limuru Town. The other key factors that were found to affect businesses in Limuru Town Market positively are; access to business information, access to infrastructure and government policy and regulations. Belay, (2015) on his part, evaluated factor that affects the development of micro and small enterprises of Mettu, Hurumu, Bede-lle and Gore Towns in Ethiopia. His finding suggested lack of experience, promotion, access to funds, poor infrastructures lack of knowledge, lack of professional assistance, lack of awareness of credit providing institution and lack of market linkage are the dominant bottleneck of small businesses.

Admasu, (2015) conducted a study on opportunities and challenges of small business enterprises in Gedio Zone of Ethiopia. His study revealed that, high tax, lack of credit access, bureaucratic burden and lack of business premises are the major problems facing small business enterprises. Mohammed, (2016) examined the challenges and prospects of small scale enterprise in Addis Ababa city, Ethiopia. His findings concluded insufficient finance, poor infrastructures, poor management practices, double taxation were the most important challenges facing small business enterprises in Ethiopia. Sharmilee, (2016) have done a research of on factors affecting the performance of small and medium enterprises in Kwazulu, South Africa. The findings indicated that, lack of competition and corruption were the major challenges of small business sectors. Babandi, (2017), reviewed critical challenges facing small business enterprises in Nigeria. The study pointed out double taxation, lack of infrastructure, corruptions, and lack of management experiences were the crucial challenges facing small 
business owners in Nigeria

\subsection{Gap Identified}

Many people argued that, challenges facing small businesses are vary from country to country. For instance, the types of problems \& its extent that small business enterprises face in developed countries like USA and developing countries like Ethiopia are quite different. Evidence indicated that, challenges facing small businesses in developing countries are very serious than developed countries. Although, there exist enormous empirical studies on issues related to challenges facing small business enterprise in many countries, in Ethiopia no study has been done on critical challenges facing small businesses in general and in Woliso town in particular. So, in the dynamic business environment, small businesses are facing with a number of challenges that requires special in sight. In this regard, it is not easy to bring sustainable growth and transformation benefit in small business sectors until those critical challenges facing small businesses are boldly identified and solved. So, the study aimed to examined critical challenges facing small business enterprises in Woliso town, in order to provide empirical evidence for better insight of the problems.

\section{Research Design and Methodology}

The research type used in the study was descriptive research. The study employed the primary data which obtained from small business owners through questionnaires. The total population of the study was 940 small business enterprises and out of which 272 was taken as a sample using probability sampling technique. Data obtained from primary sources were processed through SPSS version-22. Finally, to assist the interpretation processes pie charts, frequency tables, and bar graphs were used.

\section{Results and Discussions}

Fig. 4.1 Gender structure of respondents

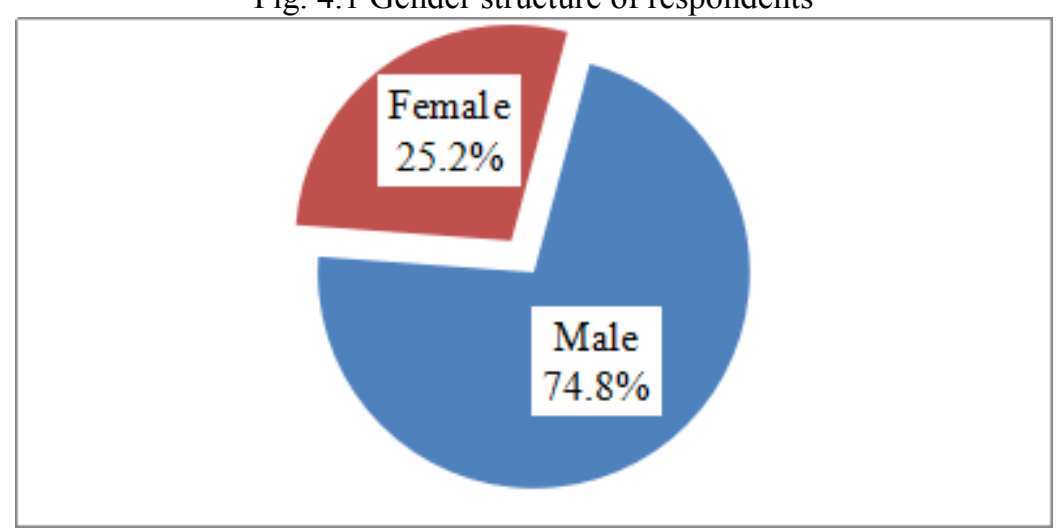

Source: Survey of small businesses, 2018

Figure 4.1 above shows the gender structure of the respondents. Accordingly, $74.8 \%$ of small business owners were owned by men whereas, the remaining $25.2 \%$ were owned by women. This indicates that, most small businesses of Woliso town were managed by men.

Fig. 4.2 Number of Individuals Employed

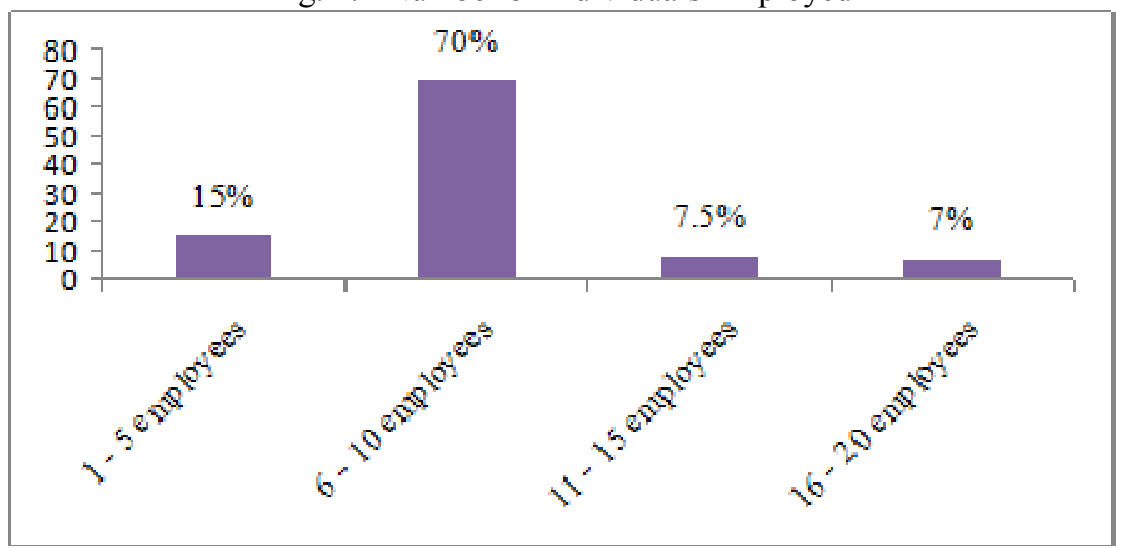

Source: Survey of small businesses, 2018

Regarding the number of employees engaged in small business of Woliso town the survey results indicated that $70 \%$ of small business owners employed between $6 \& 10$ while, $15.5 \%$ of the owners employed between $1 \&$ 5. Lastly, $7.5 \%$ and $7 \%$ of the respondents employed between $11 \& 15$ and $16 \& 20$ respectively. This shown that, 
the majority owners of small businesses employed between 6-10 workers (Fig. 4.2 shows detail).

Fig. 4.3 Respondents Academic Status

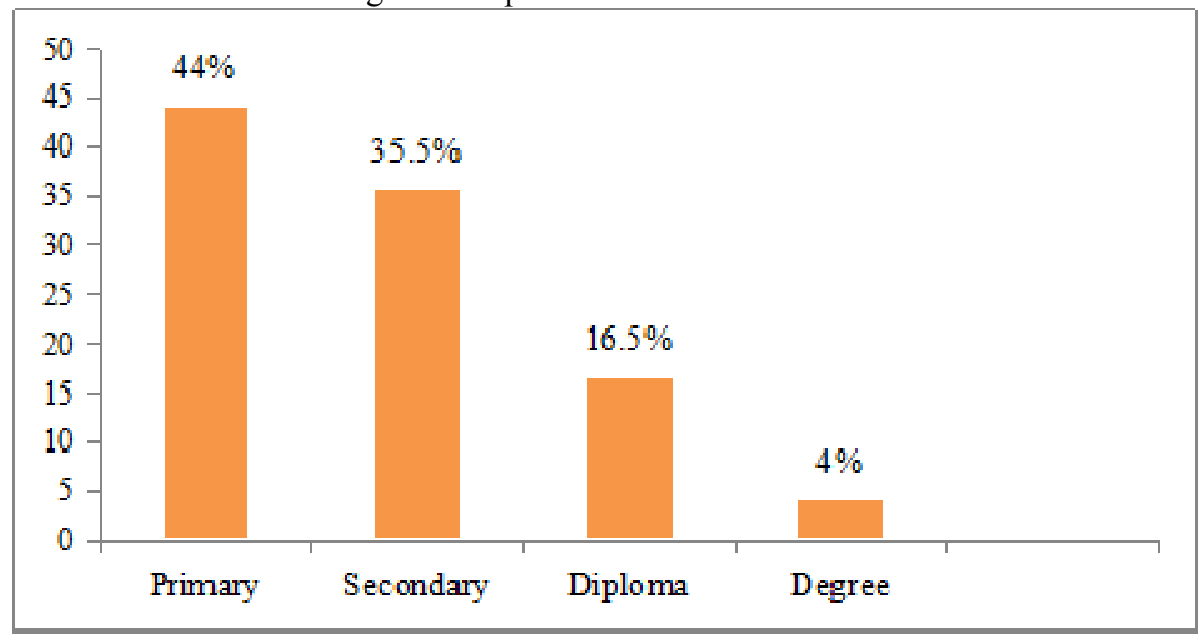

Source: Survey of small businesses, 2018

As it can be seen from figure 4.3 above, the survey result indicated, $44 \%$ and $35.5 \%$ of the respondents have primary \& secondary school education respectively. Similarly, $16.5 \%$ of the respondents have a college Diploma. And finally, only $4 \%$ of the owners have first Degree. This finding implied, most of small business owners have no enough education which enable them to maintain appropriate books of accounts and other necessary financial statements.

Table 4.1: Do you have financial constraints in your business?

\begin{tabular}{|c|c|c|c|}
\hline Response & & Frequency & $\%$ \\
\hline Yes & & 230 & 84.5 \\
\hline No & & 42 & 15.5 \\
\hline & Total & 272 & 100 \\
\hline
\end{tabular}

Source: Survey of small businesses, 2018

Table 4.1 summarizes whether owners of small businesses have financial constraints or not, accordingly, the result shows $84.5 \%$ of the respondent faces financial constraints; whereas, $15.5 \%$ have no financial constraints. This implied the significant majority of small business owners have financial constraints.

Fig. 4.4 How informal businesses affect the performance of formal businesses.

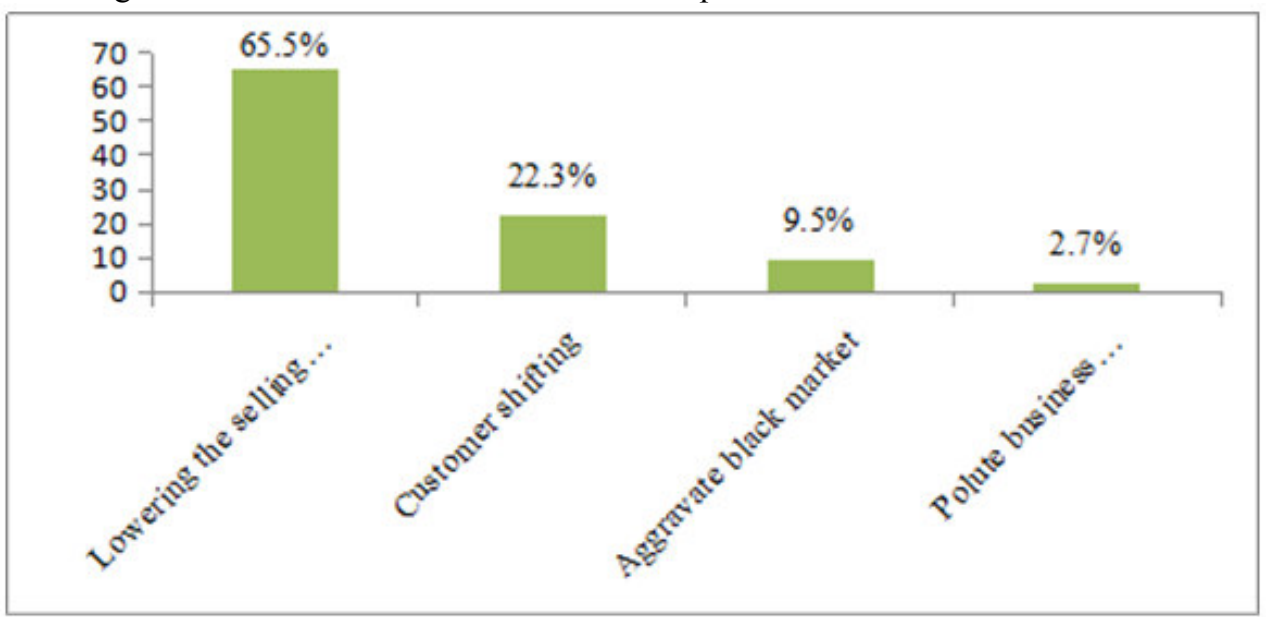

Source: Survey of small businesses, 2018

As it is clearly observed from figure 4.4 above, $65.5 \%$ of the respondent replied that informal business sectors affect the formal one by lowering the normal selling price maintained by formal businesses enterprises. In the same way, $22.3 \%$ responded that informal business sectors affect the formal business by shifting customers demand. Lastly, $9.5 \% \& 2.7 \%$ of the respondent replied that informal business sectors affect formal businesses by aggravating black market \& polluting business environments. This implied, informal business sectors significantly affect formal businesses through price reduction. 
Table 4.2: Is there any action taken by the government on informal business sectors?

\begin{tabular}{lccc}
\hline Response & & Frequency & $\%$ \\
\hline Yes & 66 & 24.4 \\
No & 206 & 75.6 \\
& & 272 & 100 \\
\hline
\end{tabular}

Source: Survey of small businesses, 2018

Regarding action taken by the government on informal sector, $75.6 \%$ of the owners replied that, there is no action taken by government authorities; whereas, $24.4 \%$ of small businesses respond that, there is government action taken by authorities in order to bring any desirable changes. This indicated that, there is little attempt by the government regarding the issues of informal business sectors whic influence the formal one. The survey results further indicated that, government measures to be taken on informal business sectors are very important. Thus, government needs to organize, train, and tries to license informal business sectors (table 4.2 shows details). Table 4.3: Do you create a business plan before starting your business?

\begin{tabular}{lccc}
\hline Response & & Frequency & $\%$ \\
\hline Yes & 14 & 5.3 \\
No & & 258 & 94.7 \\
& Total & 272 & 100 \\
\hline
\end{tabular}

Source: Survey of small businesses, 2018

Table 4.3 above asks whether small business owners create business plan or not. For this reason, $94.7 \%$ of the small business owners were not maintained business plan before starting business. However, very few, $(5.3 \%)$ of the owners were involved in preparing business plan before commencing operation. This implied that, the significant majority of small business owners were not involved in preparation of business plan. So, it is very difficult for small businesses to forecast future investments and expenditures.

Fig. 4.5 Reasons for not to prepare business plan?

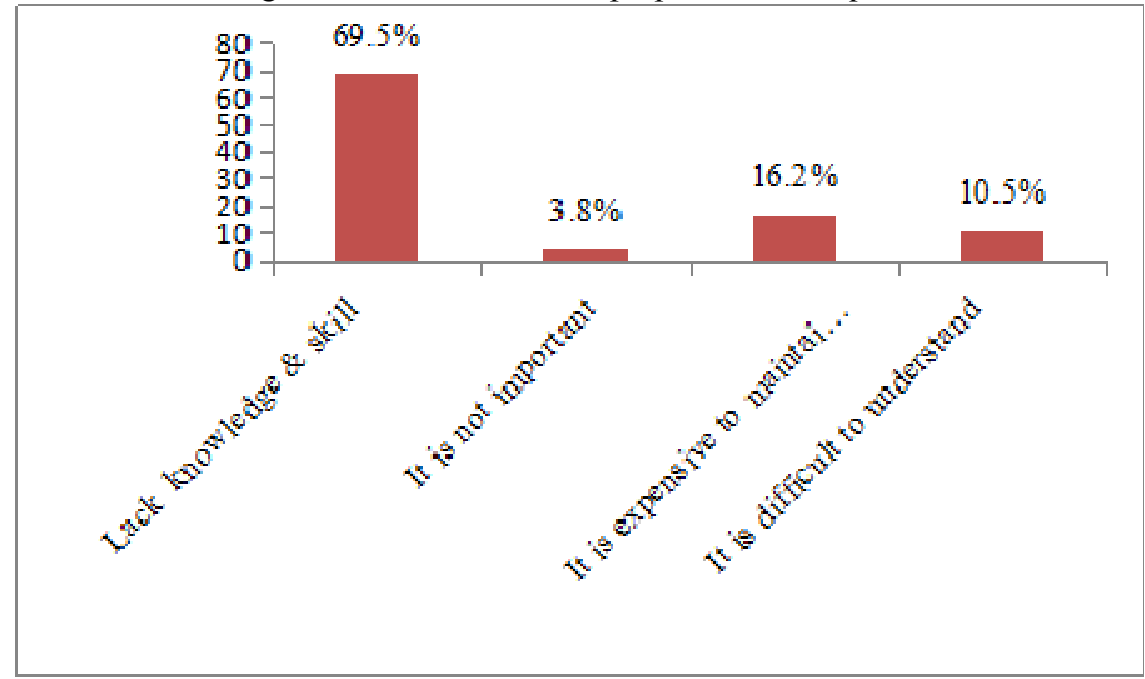

Source: Survey of small businesses, 2018

As far as business plan is much important for small business owners to better achieve their objectives $69.5 \%$ didn't prepare business plan because of lack knowledge and skill. Similarly, 16.2\% replied that, it is expensive to maintain qualified personnels who have business skill; whereas, $10.5 \%$ of the respondents replied that it is very difficult to understand the nature of business plan to be used for business practices. Lastly, $3.8 \%$ of the owners were not created business plan because of business plan is found to be unimportant. This indicated that, most small businesses were not on the position to create business plan because of lack of knowledge and skill to prepare business plan (Fig. 4.5 shows details). 
Fig. 4.6: Who manage your business?

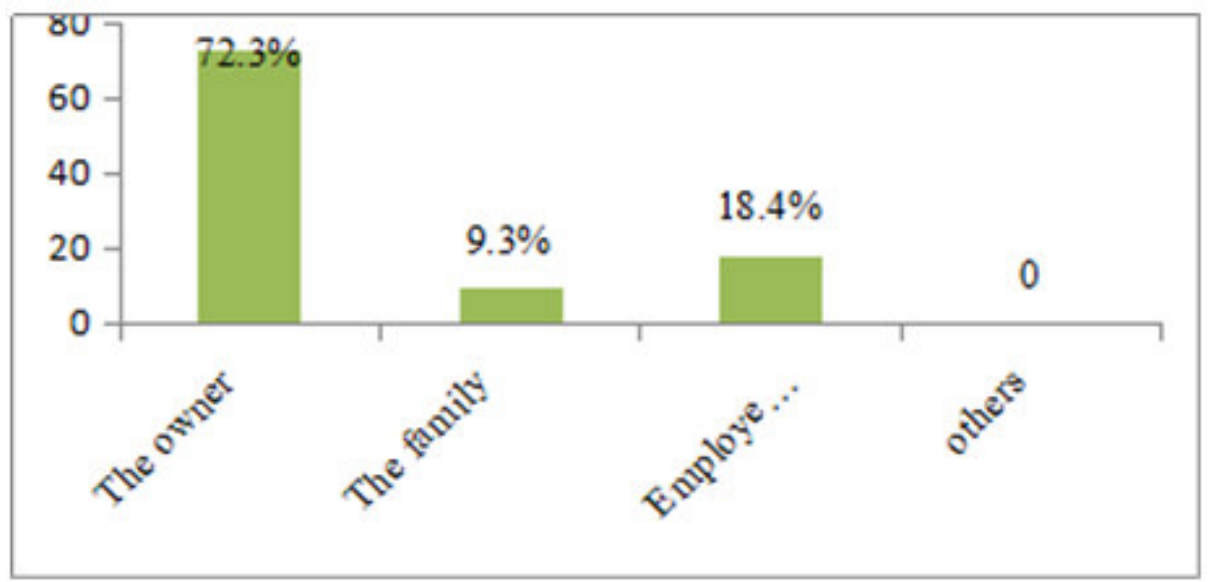

Source: Survey of small businesses, 2018

Concerning with how small businesses owners managed their businesses, figure 4.6 presents $72.3 \%$ of small business enterprises were manage $d$ by their owners. Again, $18.4 \%$ were managed by employed managers. Lastly, $9.3 \%$ of small businesses were managed by family members and none of the small business is managed by others. This finding implied that, the majority of small businesses were managed by their owners. Thus, the owners are the principal decision makers in the routine operation of their businesses.

Table 4.4: Is there any government actions that can affect your business activities?

\begin{tabular}{|c|c|c|}
\hline Response & Frequency & $\%$ \\
\hline Yes & 214 & 78.6 \\
\hline No & 58 & 21.4 \\
\hline Total & 272 & 100 \\
\hline
\end{tabular}

Source: Survey of small businesses, 2018

As it is depicted in table 4.4 above, $78.6 \%$ of the respondent replied that, there are government actions that negatively influence their business operations; whereas, $21.4 \%$ answered that no government action that affects their activities. This implied that, in most cases government action taken in small business sector influence their business decision makings.

Fig. 4.7: How government actions influences business operations

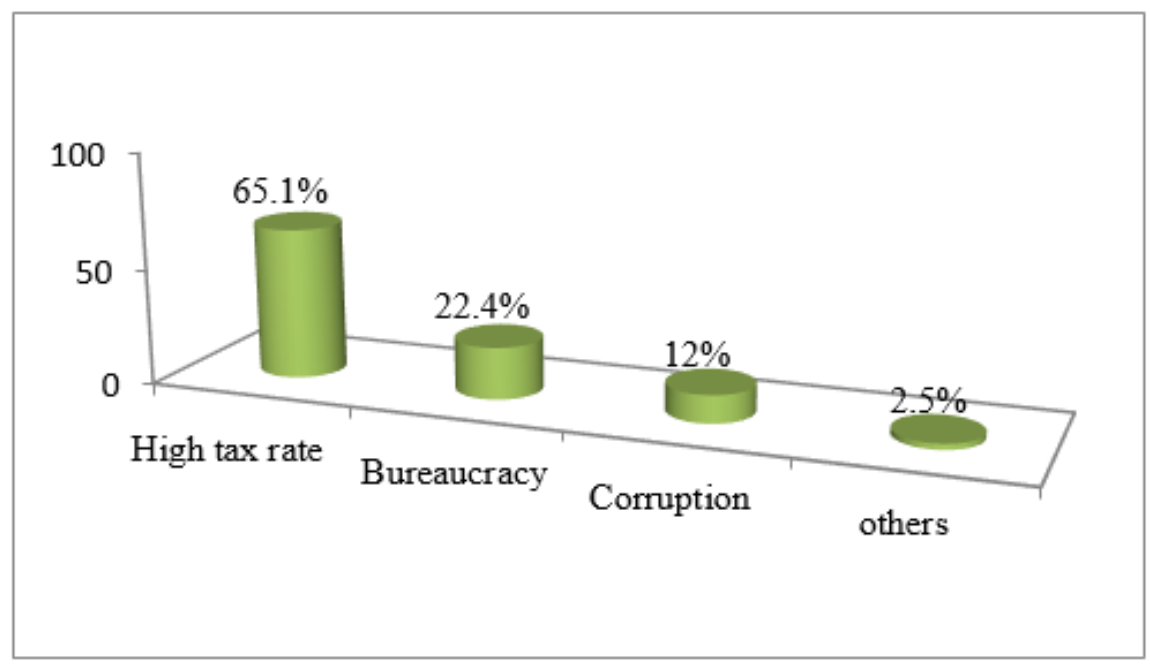

Source: Survey of small businesses, 2018

Figure 4.7 above asks as to how government action influences small business operations. As a result the survey indicated $65.1 \%$ of the owners of small businesses were affecting with high tax rate imposing by the government. Again, $22.4 \%$ of the respondents replied that bureaucratic leadership of government was another influential factor. Lastly, $12 \% \& 2.5 \%$ of the owners believe that corruption made with government officials \& other factors related to business were another actions related to government which affects businesses. This finding shows that, unreasonable tax is the most influential factor significantly affects small business activities among action taken by government units. 
Table 4.5: Do you maintain books of account for your business?

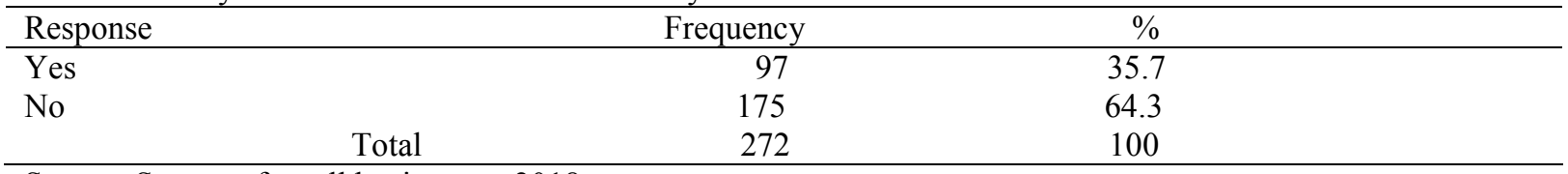

Source: Survey of small businesses, 2018

Table 4.5 above presents, whether small business owners maintain books of accounts or not? Consequently, $64.3 \%$ of the sampled businesses were not keep books of account for their businesses; whereas only $35.7 \%$ of the owners involved in the preparation of books of accounts. This result indicated that, most small business owners were not involved in maintaining books of accounts.

Fig. 4.8: Reasons for not to keep book of accounts

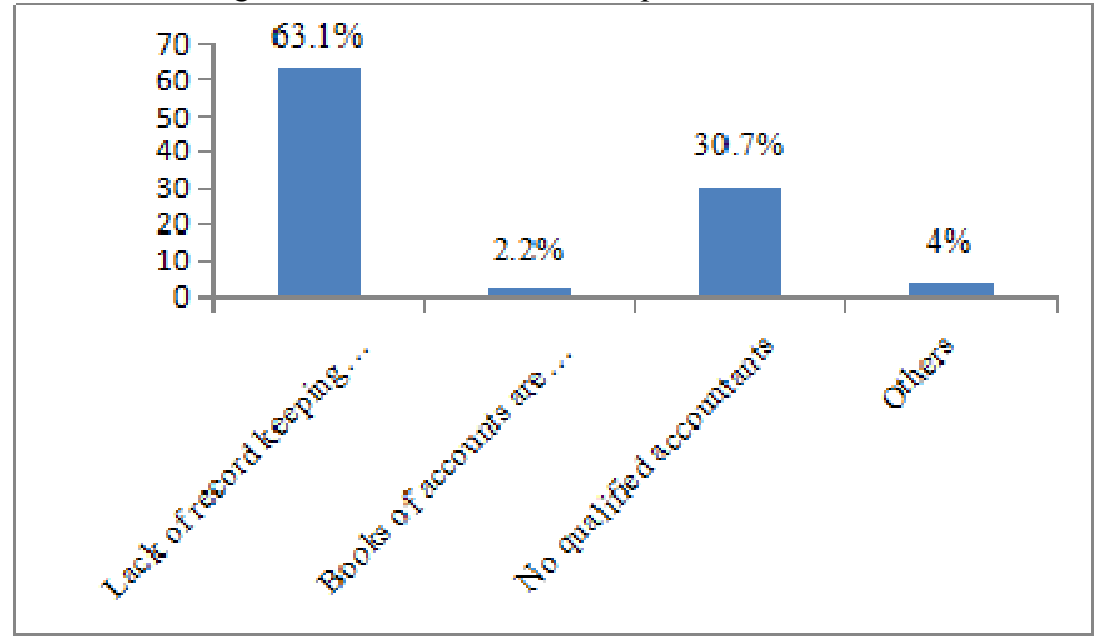

Source: Survey of small businesses, 2018

As it can be seen from figure 4.8 above, that summarizes reasons for small business owners not to keep proper books of accounts for their business; $63.1 \%$ replied that inability to maintain books of accounts is attributes to lack of record keeping skills. In the same way, 30.7\% respond that lack of qualified accountants the reason for in ability to keep books of accounts. Lastly, $4 \%$ and $2.2 \%$ of the respondents replied that others and books of accounts are not required. The implication to this finding is that, as far as books of accounts are concerned for better financial management the majority of the owners were not maintained books of account because of limitations of accounting skills.

Fig. 4.9: The most pressing challenges facing small businesses

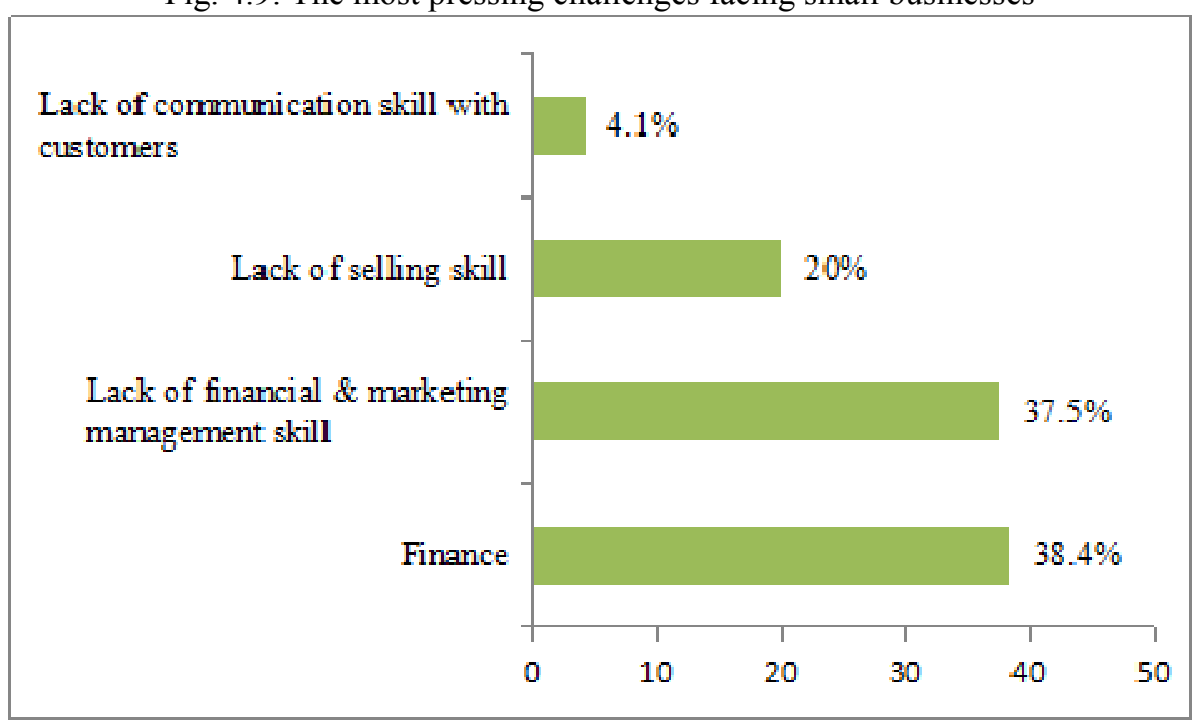

Source: Survey of small businesses, 2018

Figure 4.9 presents the most pressing challenges facing small business owners. Hence, $38.4 \%$ and $37.5 \%$ replied that the most pressing bottleneck for the owners of small businesses were attributed to shortage of finance, and lack of financial and marketing management skills respectively. Again, 20\% and 4.1\% respond that lack of selling skill and lack of communication skill with their customer respectively. This finding indicated that, 
inadequacy of finance and lack of financial \& marketing management skill were the most pressing challenges of small businesses enterprises.

\section{Findings}

The study revealed that, most (78.8\%) small businesses of Woliso town were owned by men. Similarly, the study found the majority $(70 \%)$ of small businesses owners employed between 6-10 workers and didn't have adequate knowledge to manage their businesses. The study also pointed out that, significant majority ( $84.5 \%)$ of small business owners have financial constraints. This result supports the findings of Mohamed (2016) which found small business enterprises have financial constraints because of high rate of interest and inadequate financial capacity.

The fact that the majority (65.5\%) small business owners believe that, informal business sectors significantly affect formal businesses through price reduction confirms the findings of Copisarow and Barbour, (2004) that investigate informal business sectors have negative consequences on the competitiveness and growth of formal business enterprises. As far as business plan is concerned the study identified that, the significant majority (94.7\%) of small business owners were not involved in preparation of business plan mainly because of lack of knowledge and skill. This result is consistent with the finding of Longenecker, (2006) that pointed out lack business planning and poor management were the major causes for the failure of small businesses.

Regarding small business management, the survey result indicated that the majority $(72.3 \%)$ of small businesses were managed by their owners. That is, the owners are the principal decision makers in the routine operation of their businesses. Similarly, The fact that (78.6\%) small business owners believe that government action influences their business decision makings through high tax rate and bureaucratic leadership supports what Babandi, (2017) found in the study under the research title "Critical challenges facing small business enterprises in Nigeria',

In theory of finance, the primary objective of business is profit or wealth maximization. However, the fact that most (64.3\%) small business owners were not maintained books of account is also challenging factor in order to determine the profit and loss of a particular period. Lastly, regarding with the most pressing challenges facing small business owners, the significant majority $(75.9 \%)$ believe that, the most pressing bottlenecks for the owners of small businesses were attributed to shortage of finance and lack of financial management skills. This study confirms the study done by Fetene Zeru, (2010), and Dekisiso, (2018) that found access to finance and lack of managerial skill were the pressing problems small businesses.

\section{Conclusions and Recommendations 6.1Conclusion}

From the above findings the study concluded that, most small businesses of the study area were owned by men and the majority of the owners were employed between 6-10 workers and generally with low level of education. The result also concluded that, financial constraint is one of the big challenge facing small business owners. Finally, the study found that, informal business sectors, high tax rate, bureaucratic leadership, lack of accounting and financial management skills, shortage of finance, were potential challenges of small business enterprises.

\subsection{Recommendations}

The following major suggestions were put forwarded in line with the conclusions reached.

As far as financial constraints of small business owners are concerned the authority better to design an alternative access of fund for small business owners by promoting local micro finance institutions. It is advisable for the government to attempt and put forward the appropriate remedies for the effects of informal sectors on formal small business owners. Since, unreasonable tax affects small business owners the government need to determine the appropriate tax rate imposed. Likewise, the authority better to design appropriate administration structure which better serve the interest of small business owners in order to reduce bureaucratic leadership. It is also very much important to provide continuous training for small business owners; especially academic staff of higher institution should take part to fill the skill and knowledge gap small business owners in accounting, finance, and managerial capabilities.

\section{References}

Admasu Abera, (2015). Opportunities and Challenges of Small Business Enterprises. From Policy, Regulatory and Institutional Perspectives. Asia Pacific Journal of Applied Finance Vol. 4 Issue 2, pp. 2277 - 902.

Akande, (2008). The impact of entrepreneurial skills on small business performance World Conference. Halifax, Nova Scotia: International Council for Small Business.

Arinaitwe, (2006). Factors Constraining the Growth and Survival of Small Scale Businesses. A Developing Countries Analysis. Journal of American Academy of Business, 8 (2), pp. 167-178.

Babandi Ibrahim, (2017). Critical Challenges Facing Small Business Enterprises. International Journal of 
Scientific and Engineering research Vol. 8, Issue 8, pp 2229-5518.

Belay et al, (2015). Factors affecting developments of micro and small enterprises. International Journal of Scientific and Research Publications, Vol. 5, Issue 1, pp. 2250-3153.

Brinders, et al (2003). African Renaissance 2003 Entrepreneurship and Small Business Management Development in Africa. Conference held in October 2003 at Port Elizabeth, South Africa.

Collis J. and Jarvis R., (2002). Financial information and the management of small private companies. Journal of Small Business and Enterprise Development, vol. 9, issue 2, pp.100-110.

Copisarow and Barbour, (2004). The participation of the self-employed in the shadow economy in the European Union.

Daodu O., (1997). Promoting Entrepreneurship and Small Business. Lessons of Experience. In Fadahunsi Olu and Tunji Daodu (edts) Small and Medium Enterprises Development: Policies, Programmes and Prospects. West African Management Development Institutes Network: pp 129 - 148.

Deksiso Guye, (2018). Assessment of the factors affecting the performance of micro and small scale enterprise. Journal of Development and Agricultural Economics Vol. 10(6), pp. 192-199.

Ethiopian Development Research Institute, 2017.

Ethiopian Federal Income Tax Proclamation, No. 979/2016.

Ethiopia National Planning Commission, 2015.

Fetene Zeru, (2010). Access to Finance and its Challenge for Small Business Enterprises. AAU Institutional Repository.

Hall G., (1992). Reasons for Insolvency amongst Small Firms. A Review and Fresh . Evidence, Small Business Economics 4(3):237-250.

International Labor Organization, (2008). Profile of Employment and Poverty in Africa. Report on Ethiopia, Nigeria, Ghana, Tanzania, Kenya, and Uganda. East Africa Multi-Disciplinary Advisory Team, Geneva, ILO Publications.

Lara and Simeon, (2009). Small Firm Growth in Developing Countries.

Longenecker et al, (2006). Ethical Attitudes in Small Businesses and Large Corporations: Theory and Empirical Findings from a Tracking Study Spanning Three Decades

Mbugua, et al, (2014). Factors Affecting the Performance of Small and Micro Enterprises. International Journal of Scientific and Research Publications, Vol. 4, Issue 12, p.p 2250-3153.

McMillan J. and Woodruff C., (2002). The Central Role of Entrepreneurs in Transition Economies. Journal of Economic Perspectives, Vol. 7, No 5 pp. 153-170.

Menna, (2013). Factors affecting the performance of small and medium enterprises in the manufacturing sector. International Journal of Business and Management Studies Vol. 5, No 2, pp. 1309-8047.

Mohammed, (2016). The Challenge and Prospects of Small Scale Enterprise. International Journal of Scientific and Research Publications, Volume 6, Issue 5, pp. 2250-3153

Mpendulo, (2008). Current challenges and problems facing small and medium size. African Journal of Business Management Vol. 2, No. 5, PP 093-098.

Mugenda M. and Mugenda G., (2003). Research Methods. Nairobi: Acts Press.

Okoye and Ezejiofor, (2014). The impacts of Taxation on revenue generation in Enugu, Nigeria. International journal of advanced research, vol 2, pp. 449-458.

Sanjay, (2005). The Challenges Facing Small Businesses: A Global Perspective.

Sharmilee, (2016). Factors affecting the performance of small and medium enterprises. Problems and Perspectives in Management, Volume 14, Issue 2.

Sievers M. and Vandenberg P., (2007). "Synergies through Linkages: Who Benefits from Linking MicroFinance and Business Development Services?" In World Development: Vol. 35, No. 8, pp.1341-1358

Slemrod and Venkates, (2002). The income tax compliance cost of large and midsize businesses.

Wakjira Gebresenbet, (2015). Achievements and Challenges of Micro and Small Enterprises of Addis Ababa: [Msc thesis].

Wellington D. and Mpendulo M., (2008). Current challenges and problems facing small and medium size contractors in Swaziland. African Journal of Business Management Vol.2 (5), pp. 093-098.

Werotew Bezabih, (2010). Entrepreneurship: An Engine for Sustainable Growth, Development, prosperity and Good Governance; Genius Training and Consultancy Service, Addis Ababa, Ethiopia.

Zeleke Worku,. (2009). Efficiency in Management as a Determinant of Long-term Survival in Micro, Small and Medium enterprises in Ethiopia. Problems and Perspectives in Management, 7(3): 1-9. 